\title{
Negative Regulation of Cell Death
}

National Cancer Institute

\section{Source}

National Cancer Institute. Negative Regulation of Cell Death. NCI Thesaurus. Code C40727.

Any process that decreases the frequency, rate or extent of cell death. 